\title{
Enticing teenagers into the library
}

\author{
Clare Snowball \\ Faculty of Media, Society and Culture, Curtin University of Technology, Perth, Australia
}

\section{Citation}

Snowball, C. (2008) "Enticing teenagers into the library” Library Review, vol.57 no.1, pp.25-35.

\begin{abstract}
About the author
Clare Snowball is currently undertaking a $\mathrm{PhD}$ at Curtin University of Technology investigating graphic novel collections in public libraries in Australia and teenagers' thoughts on libraries and reading, particularly reading of graphic novels. Before this Clare Snowball was a young peoples' services librarian in public libraries in Perth, Western Australia. Clare Snowball can be contacted at: clare.snowball@ @postgrad.curtin.edu.au or http://alia.org.au/ csnow/research/
\end{abstract}

\begin{abstract}
Purpose: Children and teenagers are the future adult users of libraries, and how they are treated in our libraries, particularly school and public libraries, can cement lifelong memories and habits in these young people.
\end{abstract}

Design/methodology/approach: The following paper is a review of the literature on young people's, particularly teenagers' use (or lack thereof) of libraries, the importance of library use and methods to encourage library use in young people.

Findings: Despite the findings from some of the literature that teenagers are less likely to visit libraries, there were many services and programs in libraries that aim to reverse this trend.

Research limitations: Some of the literature is peer-reviewed, but selected pieces were written by librarians in the field about their interactions with young people in their libraries. Although the latter cannot be generalised to all young people, they are important in providing examples of what occurs in some cases and what might be replicated in other settings.

Originality/value: Encouraging young people to visit and enjoy libraries can be a rewarding experience and is important in creating the next generation of library users.

Keywords: Adolescents, Youth, Public libraries, School libraries

Paper type: General review

\section{Introduction}

In every community there are people who never walk through your [library] door (Sullivan, 2005, p. 209).

It is hoped that these people are few and far between, but unfortunately this is not always the case. Many techniques are available to increase the number of people who visit libraries and lessen the number never seen. One such technique is to hook children on libraries and ensure that as they grow older, they stay hooked. Libraries provide great services and programmes to encourage children to visit and enjoy libraries and reading, but as children get older and become teenagers, they can be forgotten in the public library. US librarian Gorman (2006) believes that "teen services have to be more than an afterthought if libraries want to develop lifelong users" (p. 35).

The literature reviewed in this paper is augmented by teenagers' comments gathered from focus groups conducted as a part of the author's $\mathrm{PhD}$ research. This research is still in progress and investigates teenager's reading, library use, and what they think of reading and libraries. The names of all young people have been changed. 


\section{Do Young People use the Library?}

"I think that reading is a waste of time", said Simon (15) (Love and Hamston, 2003, p. 169).

Children "vanish" from the public library between the ages of 14 and 20 (Brown, 2004, p. 265). In the author's focus groups a number of students used to go to the public library when they were younger, but now did not. Australian librarian and teacher, Fisher (2003), investigated the opinions of students of one high school about their closest public library and found almost 40 per cent of the "student respondents only visit the library occasionally [once in the last 6 months] and 20 per cent have no contact at all" (p. 6).

One reason for the lack of young people in libraries could be that interest in reading as a leisure activity has been found to be less in teenagers aged 14 than those aged 11 (Nippold et al., 2005). Young people feel reading does not provide instant gratification (Muller, 1994) or they think it is "uncool" to read (Armstrong, 2004, p. 10; Martino, 2001, p. 61). Australian author, Agnes Nieuwenhuizen, has found teenagers "do not think books have anything to say to them" (Dobson, 1995, p. 8). Australian English teacher Chris Wheat (2003) believes, "many students have not had a pleasurable experience from a book in their lives" (p. 15).

Some of the literature counters this view. Bintz (1993) found that teenagers "lose interest in school reading as they progress through school, but do not lose interest in reading per se" (p. 613). Others have noted this phenomenon and these reluctant readers can be encouraged if they are allowed to choose their reading materials (Gutchewsky, 2001; Ivey and Broaddus, 2001; Worthy, 1998). Librarian and young adult author Jones (2000) notes that young people might not read as many books as in the past, but they still read in other formats.

Many other activities take up young people's time and reading slips down the list of things to do (Nippold et al., 2005). A study of Italian teenagers found the time they spent on reading was less than that spent on interactions with friends, watching television, and sports and hobbies (Delle Fave and Bassi, 2003). In a study of London teenagers, "only 23 per cent of teenagers listed books and reading as one of their primary leisure activities" (Dodds and Cheesman, 2003, p. 16).

\section{How to Entice Young People into the Library}

Making libraries irresistible and integral to kids isn't impossible. It just takes some work (Bolan, 2006, p. 48).

Fisher's (2003) investigation of student opinion of their closest public library found that in answer to a number of suggestions as to what students would like to find in their local library, 30 per cent said "that none of the suggestions would entice them into the public library". This could have been the answers of the "brutally honest" or the "larrikin element" (p. 7), or maybe these just were not the right suggestions. Fisher felt that the suggestions were mundane, although just the sort of thing a library's management would consider. "The generation gap [between adult library staff and young people] simply means it is easy to miss the mark" (p. 7). Fisher also mentioned some comments provided by respondents, relevant to this issue, "Staff should be nicer to us - we are not all homies or punks" (p. 11). These teenagers wanted to be treated with respect and not judged the moment they entered the library.

\section{Involving Young People in Planning}

Libraries should involve urban teens in planning and implementing services designed for them (HughesHassell and Agosto, 2006, p. 61).

Involving young people ensures "libraries are likely to be more meaningful and accessible to the groups of young people they are intended to reach" (Nairn, 2001, p. 30). Many libraries do this through a Teen Advisory Board or Youth Advisory Committee (Tuccillo, 2007). Such a group could help a library decide which activities, programmes, and services to implement and how to 
implement them. Young people may also be willing to help organise events and volunteer to help during these events.

If young people are consulted, their opinions must be genuinely considered (Minudri and Goldsmith, 1999) and the young people must also feel that they are able to influence decisions when this is possible and informed when this is not possible (Nairn, 2001). Involving young people in library planning can alleviate the generation gap mentioned above. This generation gap is also visible as "a 'techno-gap', where many youth are more technologically fluent particularly with computers than are adults" (Holm et al., 2006, p. 93). If library staff is uncertain about new technology, teenagers could be consulted (Tuccillo, 2007). One example of a library recruiting teenagers to help overcome the generation gap was at the Kitsap Regional Library in Washington State, USA. A programme called "Who's Space is it Anyway" was run by the teenagers of the library's Teen Advisory Council and initiated parents to social networking (Barack, 2007b).

\section{Events and Programs}

"We didn't think the library liked us", said a young man in response to a library event (McMillan, 2001, p. $56)$.

Programmes for teenagers can be more complicated to execute successfully than other types of programming and "require time and resources", but they are essential (Younker, 2006, p. 31). It is important to ensure "programmes capitalize on teen interests" (Saxton, 2007, p. 31), so they are attended to capacity. Successful programmes "encourage reasonable behaviour without turning away teens" (Hughes- Hassell and Agosto, 2006, p. 61). Sighthill Library in Edinburgh, Scotland, found a way to achieve this. The library "was plagued by gang fights, under-age drinking and vandalism" perpetrated young people (Ferguson, 2005). Banning the culprits was not working and so the library created a dedicated area for youth and partnered with Lothian and Borders Police and the Duke of Edinburgh Award Scheme, to deliver programmes. These included the Computer Crazies Club, learning how to compile a CV, and producing video diaries about life in Sighthill. A library staff member, Andrew McTaggat said, "The library is now used as a real community centre for these kids" (Ferguson, 2005).

New Brighton Community Library in Christchurch, New Zealand had a similar problem with young people disturbing older users of the library and found an innovative solution to the situation. The problem arose when a new library was built in New Brighton, a suburb of Christchurch, and the entrance proved perfectly designed for skateboarding. Young people in the area took full advantage of this, while disturbing people who were trying to enter the library. In order to solve these problems, while not alienating potential new library users,

staff decided to run a skateboarding workshop in the amphitheatre at the southern end of the building. It was hoped that by doing this, the library would be able to communicate to its younger users that libraries could be fun and exciting places, but also that respect for all library users was necessary (p. 54).

Feedback from participants was overwhelmingly positive. In reply to questions as to whether the library should be holding such events, "the library responded that as a community place, it was important to be in touch with the needs and desires of the community" (p. 56).

Many libraries collect anime and manga (Japanese animated movies and TV shows and comics), which are popular with young people. These collections can lead to programming ideas. Anime clubs are proliferating in public libraries. This involves showing an anime movie or a few episodes of an anime TV show. Attendees also talk about anime and manga, sketch characters and eat Japanese snacks such as Pocky (Brehm-Heeger et al., 2007). Cosplay involves dressing as a character from anime or manga. Anime club members may attend meetings in costume or a separate cosplay event could be planned. Prizes are awarded for "the effort put into assembling the costume, realistic portrayal of the character, and creativity" (Brehm-Heeger et al., 2007, p. $15)$. 
When events are held in the library, promotion is vital and this ensures events are attended to capacity. Hughes-Hassell and Agosto (2006) discussed the usefulness of advertising in promoting the library in general, but specific aspects of the library can be advertised just as effectively. Posters and flyers should be displayed inside the library as well as at places where young people spend time, for example, schools, shopping centres, and sporting events (Minudri and Goldsmith, 1999; Spelman, 2001). New Zealand public librarian Viv Smith (2006) suggests using the technology which young people use to promote events, as well as the local newspaper and radio station. Food and drinks are an integral part of events for young people (Tuccillo, 2007). Snacks or pizza are always popular and fruit juice is a healthier option than soft drink.

\section{Technology in the Library}

Libraries need to "stay relevant by changing with these fast-moving times" (Kenney, 2006, p. 11).

Many libraries collect anime and manga (Japanese animated movies and TV shows and comics), which are popular with young people. These collections can lead to programming ideas. Anime clubs are proliferating in public libraries. This involves showing an anime movie or a few episodes of an anime TV show. Attendees also talk about anime and manga, sketch characters and eat Japanese snacks such as Pocky (Brehm-Heeger et al., 2007). Cosplay involves dressing as a character from anime or manga. Anime club members may attend meetings in costume or a separate cosplay event could be planned. Prizes are awarded for "the effort put into assembling the costume, realistic portrayal of the character, and creativity" (Brehm-Heeger et al., 2007, p. $15)$.

When events are held in the library, promotion is vital and this ensures events are attended to capacity. Hughes-Hassell and Agosto (2006) discussed the usefulness of advertising in promoting the library in general, but specific aspects of the library can be advertised just as effectively. Posters and flyers should be displayed inside the library as well as at places where young people spend time, for example, schools, shopping centres, and sporting events (Minudri and Goldsmith, 1999; Spelman, 2001). New Zealand public librarian Viv Smith (2006) suggests using the technology which young people use to promote events, as well as the local newspaper and radio station. Food and drinks are an integral part of events for young people (Tuccillo, 2007). Snacks or pizza are always popular and fruit juice is a healthier option than soft drink. MP3 file on a compact disc provides another format for "reading" (or listening to) books.

Some recognize gaming as a "literacy activity" (Bolan et al., 2007, p. 42) and the "positive social aspects of gaming are wide-ranging" (Neiburger and Gullett, 2007, p. 34). Libraries have loaned video games (usually on CD-ROM) for a number of years, but libraries are now installing gaming consoles, such as Xbox or Playstation 2, to attract young people (Saxton, 2007).

Because of the broad appeal of video games, especially among today's teens, gaming events have the ability to bring together players from different schools, cliques, races, ages, or cultures, and give them a relatively level playing field that they can't find anywhere else (Neiburger and Gullett, 2007, p. 35).

Elizabeth Beales (2006) from the Barossa Public Library in South Australia wrote about installing an Xbox gaming console in her library. In a subsequent issue of the publication a letter to the editor stated, "an Xbox console in a library will not make a child discover books and reading; quite the opposite" (Williams, 2006, p. 5). The view that libraries are not just about books and reading, but information in general, would counter this reaction. By coaxing teenagers into the library we can then show them the many forms of information and entertainment that are available at their library and perhaps at the same time "show them that turning pages is nearly as much fun as manoeuvring a joystick!” (Beales, 2006, p. 8). Once a gaming console has been installed in a library, it is available for tournaments and free-play events (Saxton, 2007). As in other areas, local teenagers can be involved in the choice of system and appropriate games for events. This will help them feel ownership and ease problems of librarians' lack of knowledge. 
More low-tech games such as chess and board games can be combined with video game events or held as events on their own.

Web 2.0 "is the next generation of the Internet" (Bolan et al., 2007, p. 40). Web 2.0 tools allow users of the web to contribute content more easily and use the web for communication and collaboration in a simpler manner than has previously been possible. The tools that make up Web 2.0 include blogs, social networking sites, wikis, photo sharing sites, video sharing sites, and bookmark sharing sites (Kenney, 2007; Oleck, 2006; Richardson, 2007). They are important for young people because "it is where reading and learning takes place, where recreational needs are met, communities are formed, and knowledge is constructed" (Kenney, 2007, p. 11). These sites also give young people a voice (Adam and Mowers, 2007).

A blog which is regularly updated can encourage people to revisit a library's website (Sauers, 2006) and this can be particularly effective with young people. Topeka and Shawnee County Public Library in Kansas, USA hosts a blog for teenagers called Graffiti: the YA Blog, accessible from http://graffiti.tscpl.org/ (accessed 27 April 2007). Library staff post messages about library events, celebrity news, websites, new books coming out, and other items of interest to teenagers.

Blogs can also directly encourage reading of books, something that not many online tools do. Book blogs offer information as diverse as reviews, publishing news, author interviews, and challenges to read the most books in $48 \mathrm{~h}$ (Burns, 2007). Eighth grade history teacher, Eric Langhorst (2006), has used book blogs with his students, their parents, authors, and others who stumble on the blog. The author of one of the books, Pat Hughes, who took part in a blog with his students, said, "In the hands of a superior teacher like Eric, you can rally see how the Web can be utilized to engage and excite students" (p. 48).

A social networking website is an "online place where a user can create a profile and build a personal network that connects him or her to other users" (Lenhart and Madden, 2007, p. 1). Many libraries and authors of books for young people have a profile on MySpace (MySpace and Teens, 2007). MySpace is one of the social networking sites which are popular with teenagers (Lenhart and Madden, 2007). Teen Services Librarian Rapacki (2007) believes this is because "the web can be the ideal means for navigating the waters of self discovery" (p. 28). There is discussion about whether it is appropriate for libraries to have a profile on MySpace. "Social networking sites have become the virtual commons where teens go to hang out with their friends" (Rapacki, 2007, p. 29) and some people question whether libraries or librarians joining this space are an invasion of privacy. The "invisible line between teen's private space and their more public space is not as apparent as it once was" (Alternative Teen Services, 2007).

A wiki is "an open-styled web page that allows any registered user the opportunity to write and edit at will" (Barack, 2007a, p. 22). Wikipedia, accessible from http://www.wikipedia.org/ (accessed 27 April 2007) is the largest (and one of the first) wikis. Many young people use Wikipedia for all their information needs, for example, for school assignments, but it is not always reliable as anyone can alter entries (Rosenzweig, 2006). Many librarians are using wikis to share knowledge, for example, the ChildTech Wiki, accessible from http://wikis.ala.org/alsc/index.php/ALSC_ChildTech_Wiki (accessed 27 April 2007). People are even trying to write books using wikis (Barack, 2007a). A Million Penguins is accessible from http://www.amillionpenguins.com/ (accessed 27 April 2007). The wiki has been locked from contributions, but can still be read. The children's book Witches and Wiki is accessible from http://witchesandwiki.pbwiki.com/ (accessed 27 April 2007). The author found A Million Penguins difficult to read, although not all of the story was read. Perhaps the disconnected first parts come together at some point. This disconnection may have been caused by the number of authors. Witches and Wiki was more enjoyable, full of suspense, and easier to read (although this is to be expected because it is written for children). It does still need editing. 
Youth literature website, Inside a Dog, accessible from http://www.insideadog.com.au/ (accessed 27 April 2007) and the Young Australian Readers' Award, accessible from http://www.yara-online.org/ (accessed 27 April 2007) have book reviews written by young people. Reviews from young library users are easily solicited and uploaded to a library's website or blog. This is also being done when libraries offer summer reading programmes online (Bolan et al., 2007). Yarra Plenty Regional Library in Australia created a wiki for their summer reading club and children wrote and posted their own book reviews over the summer. The wiki is accessible from http://summerreadingclub.pbwiki.com/ (accessed 27 April 2007).

Australian teacher librarian Chapman (2004) discussed online book raps which are book discussions conducted by e-mail. They usually last for five to six weeks, with introductions in the first week and a new discussion point e-mailed weekly. "The rap Wrap Up occurs during the last week, inviting rappers to share reflections on the rap experience" (p. 112). Chapman considers their educational uses, but book raps could just as easily be conducted by public libraries. Successful book raps conducted in New South Wales schools are accessible from http://www.schools.nsw.edu.au/raps/ (accessed 27 April 2007).

Before the advent of high-tech media, book discussions were held in libraries, as they still are. This "offers an opportunity for libraries to draw new teens into the building and keep active patrons involved" (Gallego, 2006, p. 176). Australian librarian Spelman (2001) discussed family reading groups and reading groups for teenagers. In her review of The teen-centered book club, US librarian Gallego (2006) discussed the need to make reading groups for teenagers "focus on the participants rather than the books", unlike their adult counterparts (p. 176). A school library in New Jersey, USA started a book discussion group called Lit Chicks and since then, "the school's library circulation has more than doubled" (Tuccillo, 2007, p. 47).

Inside a Dog, accessible from http://www.insideadog.com.au/ (retrieved 27 April 2007) has a writer in residence, who changes every month. He or she writes a blog about writing and visitors to the site can post comments and questions and the writer will reply. Children's author, Jon Scieszka, has developed a website called Guys Read accessible from http://www.guysread.com (accessed 27 April 2007) to encourage boys to read and to call attention to boys' literacy. It has sections for boys and for adults interested in boys' literacy. The site promotes "boy-friendly nonfiction, humor, comics, graphic novels, action-adventure, magazines, websites, and newspapers . .. [and] that all these materials count as reading" (Scieszka, 2005). Scieszka believes, "if you find the right stories to hook them, boys will read" (Hayes cited in Block, 2003, p. 57).

Despite the advantages of today's technology, there can be problems in cyberspace.

Cyberbullying (harassment by electronic means) is a recent phenomenon (Anderson and Sturm, 2007), not even discussed in an Australian survey of Internet use published in 2001 (Aisbett, 2001). Cyberbullying may occur anywhere with access to technology, such as a library. The anonymity of online technologies can make cyberbullying easier to perpetuate and harder to trace (Anderson and Sturm, 2007). Annabel Beckenham, the deputy head of the University of Canberra (Australia) School of Communication said, "technology such as the Internet did not cause bullying, but made it easier to perpetuate...People do and see things online that they would not normally do" (Powell, 2006, p. 29). A number of books and websites aimed at children and parents discuss the phenomenon and what to do if it is experienced (Williard, 2007; Centre for Safe and Responsible Internet Use, 2007; Wired Safety, 2007). Children's and young adult books are starting to be written about cyberbullying, for example, Destroying Avalon by McCaffrey (2006). Librarians can use these resources to educate themselves, and also educate parents and young people who visit the library. 


\section{Making the Library Inviting}

Neighbourhood organizations "need to create environments in which young people can share a sense of responsibility and purpose and experience the benefits of building a community...Libraries could help to create these urban sanctuaries for young people, within their walls and elsewhere in the community" (Walter, 2001, p. 105).

Spaces in libraries designed to attract young people "have been advocated as a way to correct a long-standing institutional bias against youth culture" (Cranz and Cha, 2006, p. 48). In the last ten years, "many libraries have transformed their young adult areas into more efficient, innovative, and inspirational spaces" (Bolan, 2006, p. 44).

A high school student surveyed by Fisher (2003) said, "The perfect public library would have a better atmosphere, colours and posters" (p. 10). The first step in designing that perfect library should be to ask young people what they want in "their" space (Bolan, 2006, p. 45). A section of the teen space at London Public Library in Ontario, Canada was painted by local graffiti artist Bryan Jesney. Photographs of the work in progress were posted to Flickr (London Public Library, 2007). Using such websites (or even a library's own website) to display photos of young people in libraries "gives the library a human face" (Bolan et al., 2007, p. 43). The redesigned Cesar Chavez Library which Cranz and Cha (2006) investigated, decorated their teen area with posters of Bruce Lee, Tupac Shakur, and The Simpsons.

Unfortunately we all judge books by their covers (Wilson, 2000), thus "libraries should always have materials that are new and exciting" (Sullivan, 2005, p. 73). No one likes finding "ragged, unpleasant-looking, or unpleasant-smelling items in the library" (p. 69). Cassie (14), in the author's focus group, agreed when she disparagingly said, "Some of the books in our library are really old". To make these exciting covers noticeable, items can be displayed face out (Cranz and Cha, 2006). This can usually only be done for some of the collection as it takes more shelf space.

The shelf arrangement of a collection has the potential to make it "exceedingly difficult for your customers and staff members to navigate" the library (Sullivan, 2005, p. 61). Cassie (14), in the author's focus group, said her school library "put them [books] in alphabetical order...You pick up a book and you don't have any idea what it's about". When asked if it would be better to order the books by genre, she agreed, as this was how her local public library was arranged. "Readers enjoy browsing, so making the experience simpler and more fruitful will attract readers" (Sullivan, 2005, p. 99) and browsing is facilitated by arranging items by subject in nonfiction and genre in fiction (Bolan, 2006).

\section{Conclusion}

The necessity for encouraging young people to frequent and enjoy going to libraries can be enabled through a number of means which many libraries are already implementing. The activities that young people voluntarily take part in can be incorporated into libraries and library events to encourage young people to visit the library and tell everyone they know what a cool place it is. Some libraries may be able to implement a number of the ideas discussed in this paper, but most libraries could only undertake some of them. To paraphrase US librarian Karen Schnieder, decide on five techniques that are desirable and focus on three. "This less-is-more approach" will ensure that the ideas a library undertakes will be accomplished successfully (Schneider, 2007). Once young people are enticed into the library, "you just never know what amazing things can happen!” (Brehm-Heeger et al., 2007, p. 16). 


\section{Reference list}

Abbas, J., Bishop, K. and D'Elia, G. (2007), "Youth and the internet", Young Adult Library Services, Vol. 5 No. 2, pp. 44-9.

Adam, A. and Mowers, H. (2007), "YouTube comes to the classroom", School Library Journal, Vol. 53 No. 1, p. 22.

Aisbett, K. (2001), The Internet at Home: A Report on Internet Use in the Home, Australian Broadcasting Authority, Sydney, NSW.

Alternative Teen Services (2007), "MySpace, YourSpace: are libraries infringing on teen privacy?", 2 February, available at: http://www.yalibrarian.com/wordpress/2007/02/myspace-yourspaceare-librariesinfringing-on-teen-privacy/ (accessed 27 April 2007).

Anderson, T. and Sturm, B. (2007), "Cyberbullying: from playground to computer", Young Adult Library Services, Vol. 5 No. 2, pp. 24-7.

Armstrong, E. (2004), Fully Booked: Reader Development and the Secondary School LRC, School Library Association, Wanborough.

Barack, L. (2007a), "Never-ending story”, School Library Journal, Vol. 53 No. 3, pp. 22-3.

Barack, L. (2007b), “Teens 'n Tech”, School Library Journal, Vol. 53 No. 4, p. 22.

Beales, E. (2006), "What does an Xbox have to do with reading?", Incite, Vol. 27 No. 3, p. 8.

Bintz, W.P. (1993), "Resistant readers in secondary education: some insights and implications", Journal of Reading, Vol. 36 No. 8, pp. 604-15.

Block, M. (Ed.) (2003), Net Effects: How Librarians can Manage the Unintended Consequences of the Internet, Information Today, Medford, NJ.

Bolan, K. (2006), "Looks like teen spirit", School Library Journal, Vol. 52 No. 11, pp. 44-8.

Bolan, K., Canada, M. and Cullin, R. (2007), "Web, library, and teen services 2.0", Young Adult Library Services, Vol. 5 No. 2, pp. 40-3.

Brehm-Heeger, P. (2006), "Keeping up with the new", School Library Journal, Vol. 52 No. 3, p. 46.

Brehm-Heeger, P., Conway, A. and Vale, C. (2007), "Cosplay, gaming, and conventions: the amazing and unexpected places an Anime Club can lead unsuspecting librarians", Young Adult Library Services, Vol. 5 No. 2, pp. 14-6.

Brown, A. (2004), "Reference services for children: information needs and wants in the public library", Australian Library Journal, Vol. 53 No. 3, pp. 261-74.

Burns, E. (2007), "Curl up with a cup of tea and a good blog", School Library Journal, Vol. 53 No. 2, pp. 40-2.

Center for Safe and Responsible Internet Use (2007), "Prevention and intervention of cyberbullying", available at: http://cyberbully.org/ (accessed 27 April 2007).

Chapman, W. (2004), "Book raps", in Bales, J. and Bonanno, K. (Eds), Constructing Communities of Learning and Literacy: ASLA Online Conference 2004 Proceedings, ASLA, Zillmere, Qld, pp. 112-7.

Cranz, G. and Cha, E. (2006), "Body-conscious design in a teen space: post-occupancy evaluation of an innovative public library", Public Libraries, Vol. 45 No. 6, pp. 48-56.

Curtin University Library (2007), "Curtin University library podcast", 12 April, available at: http://library.curtin.edu.au/podcast/ (accessed 27 April 2007).

Delle Fave, A. and Bassi, M. (2003), "Italian adolescents and leisure: the role of engagement and optimal experience", New Directions for Child and Adolescent Development, Vol. 99, pp. 79-93.

Dobson, B. (1995), “An interview with Agnes Nieuwenhuizen”, Reading Time, Vol. 39 No. 4, pp. 7-9.

Dodds, I. and Cheesman, R. (2003), "Reading remix: consulting young people in South-East London", in Dodds, I. (Ed.), Reading Remixed: New approaches to Library Services for Teenagers, Youth Libraries Group, London, pp. 14-17. 
Ferguson, B. (2005), "Award for the library that lent support", The Scotsman, 27 September, available at: http://news.scotsman.com/edinburgh.cfm?id=2000692005 (accessed 27 April 2007).

Fisher, H. (2003), "A teenage view of the public library: what are the students saying?", APLIS: Australian Public Library and Information Services, Vol. 16 No. 1, pp. 4-16.

Gallego, B. (2006), "Professional reading: the teen-centered book club", School Library Journal, Vol. 52 No. 11, p. 176.

Gorman, M. (2006), “Stir it up”, School Library Journal, Vol. 52 No. 2, p. 35.

Gutchewsky, K. (2001), “An attitude adjustment: how I reached my reluctant readers", English Journal, Vol. 91 No. 2, pp. 79-85.

Holm, G., Daspit, T. and Young, A.J.K. (2006), "The sky is always falling”, in Leccardi, C. and Ruspini, E. (Eds), A New Youth? Young People, Generations and Family Life, Ashgate, Aldershot, pp. 85-102.

Hughes-Hassell, S. and Agosto, D.E. (2006), "Planning library services for inner-city teens: implications from research", Public Libraries, Vol. 45 No. 6, pp. 57-63.

Ivey, G. and Broaddus, K. (2001), "Just plain reading: a survey of what makes students want to read in middle school classrooms", Reading Research Quarterly, Vol. 36 No. 4, pp. 35077.

Jones, P. (2000), "Connecting young adults and libraries: creating raving fans into the 21 st century", Orana, Vol. 36 No. 1, pp. 24-8.

Kenney, B. (2006), “A challenge to library directors", School Library Journal, Vol. 52 No. 11, p. 11.

Kenney, B. (2007), "You 2.0”, School Library Journal, Vol. 53 No. 1, p. 11.

Langhorst, E. (2006), “The dixie clicks”, School Library Journal, Vol. 52 No. 12, pp. 46-8.

Lenhart, A. and Madden, M. (2007), Social Networking Websites and Teens: An Overview, Pew Internet and American Life Project, Washington, DC, available at: http://www.pewinternet.org/PPF/r/198/report_display.asp (accessed 27 April 2007).

London Public Library (2007), "Teenannex: a photoset on Flickr", 19 January, available at: http://www.flickr.com/photos/londonpubliclibrary/sets/72157594415192325/ (accessed 27 April 2007).

Love, K. and Hamston, J. (2003), "Teenage boys' leisure reading dispositions: juggling male youth culture and family cultural capital”, Educational Review, Vol. 55 No. 2, pp. 16177.

McCaffrey, K. (2006), Destroying Avalon, Fremantle Arts Centre Press, Fremantle, WA.

McMillan, D. (2001), "Getting connected: new ways to attract the young", APLIS: Australian Public Library and Information Services, Vol. 14 No. 2, pp. 52-7.

Martino, W. (2001), "Boys and reading: investigating the impact of masculinities on boys' reading preferences and involvement in literacy", Australian Journal of Language and Literacy, Vol. 24 No. 1, pp. 61-74.

Minudri, R. and Goldsmith, F. (1999), "The top 10 things you need to know about teens", School Library Journal, Vol. 45 No. 1, pp. 30-1.

Muller, V. (1994), "The 'I hate reading' book club: what a challenge, and how did it come about?" in Nieuwenhuizen, A. (Ed.), The Written World: Youth and Literature, D.W. Thorpe, Melbourne, pp. 92-5.

MySpace and Teens (2007), 8 February, available at: http://www.libsuccess.org/index.php?title=MySpace_\%26_Teens (accessed 27 April 2007).

Nairn, K. (2001), "Young people's participation: what does it mean for libraries and librarians?", APLIS: Australian Public Library and Information Services, Vol. 14 No. 1, pp. 25-31.

Neiburger, E. and Gullett, M. (2007), "Out of the basement: the social side of gaming", Young Adult Library Services, Vol. 5 No. 2, pp. 34-6, 38. 
Nippold, M.A., Duthie, J.K. and Larsen, J. (2005), "Literacy as a leisure activity: free-time preferences of older children and young adolescents", Language Speech and Hearing Services in Schools, Vol. 36 No. 2, pp. 93-102.

Oleck, J. (2006), "Librarians embrace the digital world", School Library Journal, Vol. 52 No. 12 , p. 18.

Powell, R. (2006), "Trouble in cyber space", The Canberra Times, 3 December, p. 29.

Rapacki, S. (2007), "Social networking sites: why teens need places like MySpace", Young Adult Library Services, Vol. 5 No. 2, pp. 28-30.

Richardson, W. (2007), "Taming the beast", School Library Journal, Vol. 53 No. 3, pp. 50-1.

Rosenzweig, R. (2006), "Can history be open source? Wikipedia and the future of the past", The Journal of American History, Vol. 93 No. 1, pp. 117-46.

Sauers, M.P. (2006), Blogging and RSS: a librarian's guide, Information Today, Medford, NJ.

Saxton, B. (2007), “All thumbs isn't a bad thing: video game programs @ your library”, Young Adult Library Services, Vol. 5 No. 2, pp. 31-3.

Schneider, K.G. (2007), "IT and sympathy", ALA TechSource, 19 January, available at: http://www.techsource.ala.org/blog/2007/01/it-and-sympathy.html (accessed 27 April 2007).

Scieszka, J. (2005), "Guys read”, available at: http://www.guysread.com (accessed 27 April 2007).

Smith, V. (2006), "So who says young adults need libraries?", paper presented at the RISE Youth Seminar, Wellington, NZ, available at: http://www.wcl.govt.nz/about/services/rise.html (accessed 27 April 2007).

Spelman, A. (2001), "Reading groups for young people", APLIS: Australian Public Library and Information Services, Vol. 14 No. 2, pp. 46-51.

Sullivan, M. (2005), Fundamentals of Children's Services, American Library Association, Chicago, IL.

Tuccillo, D. (2007), "Standing room only", School Library Journal, Vol. 53 No. 3, pp. 46-8.

Walter, V.A. (2001), Children and Libraries: Getting it Right, American Library Association, Chicago, IL.

Wheat, C. (2003), "The lesson for today is popular culture", The Age, 30 January, p. 15.

Williams, J. (2006), "Your voice: Xboxes in libraries", Incite, Vol. 27 No. 4, p. 5.

Williard, N.E. (2007), Cyber-Safe Kids, Cyber-Savvy Teens, Jossey-Bass, San Francisco, CA.

Wilson, M. (2000), "Understanding the needs of tomorrow's library user: rethinking library services for the new age", APLIS: Australian Public Library and Information Services, Vol. 13 No. 2, pp. 81-6.

Wired Safety (2007), "Cyber911 Emergency: Cyberbullying”, available at: http://www.wiredsafety.org/cyberstalking_harassment/cyberbullying.html (accessed 27 April 2007).

Worthy, J. (1998), “On every page someone gets killed! Book conversations you don't hear in school", Journal of Adolescent \& Adult Literacy, Vol. 41 No. 7, pp. 508-17.

YALSA (2007), Teens and Social Networking in School and Public Libraries: A Toolkit for Librarians and Library Workers, Young Adult Library Services Association, Chicago, IL, available at: http://teentechweek.wikispaces.com/space/showimage/SocialNetworkingToolkit.pdf (accessed 27 April 2007).

Younker, J.M. (2006), “Where is the love?", School Library Journal, Vol. 52 No. 12, p. 31. 